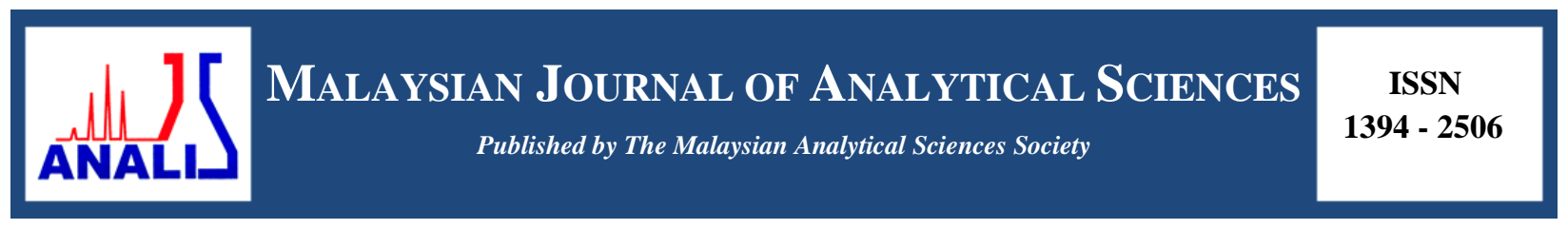

\title{
EVALUATION OF HEAVY METAL CONCENTRATIONS IN WILD AND CULTIVATED Hemibagrus sp. USING PRINCIPAL COMPONENT ANALYSIS
}

\author{
(Penilaian Kepekatan Logam Berat dalam Hemibagrus sp. dari Habitat Semulajadi dan Kolam \\ Ternakan Menggunakan Kaedah Analisis Komponen Utama)
}

\author{
Nor Shahirul Umirah Idris ${ }^{1}{ }^{1}, 3 *$, Sharifuddin Md.Zain ${ }^{1}$, Kah Hin Low ${ }^{1}$, Ahmad Firdaus Kamaruddin ${ }^{4}$ \\ Kaharudin Md. Salleh ${ }^{5}$ \\ ${ }^{I}$ Environmental Research Group, Department of Chemistry, Faculty of Science \\ ${ }^{2}$ Institute of Graduate Studies \\ University of Malaya, 50603 Kuala Lumpur, Malaysia \\ ${ }^{3}$ Faculty of Earth Science, \\ Universiti Malaysia Kelantan Kampus Jeli, Karung Berkunci No.100, 17600 Jeli, Kelantan, Malaysia \\ ${ }^{4}$ East Coast Environmental Research Institute (ESERI), \\ Universiti Sultan Zainal Abidin, Gong Badak Campus, 21300 Kuala Terengganu, Terengganu, Malaysia \\ ${ }^{5}$ Fisheries Research Institute, Freshwater Fisheries Research Division, \\ Glami Lemi, 71650 Titi, Jelebu, Negeri Sembilan, Malaysia \\ *Corresponding author: shahirulumirah@gmail.com
}

Received: 24 February 2015; Accepted: 27 October 2015

\begin{abstract}
In the present study, the concentration of $\mathrm{Cr}, \mathrm{Cd}, \mathrm{Cu}, \mathrm{Zn}, \mathrm{Pb}$, and $\mathrm{As}$ in various tissues of Hemibagrus sp. from two different habitat were determined with microwave assisted digestion-inductively coupled plasma-mass spectrometry. The objective of this research was to determine the differences between wild and cultivated in terms of heavy metal accumulation in muscle, liver and gills tissues. The metals accumulation pattern relating types of tissue and elements as well as fish habitats were revealed by principal component analysis. The results revealed that variation in metal accumulation pattern is strongly dependent on the type of tissues. The results suggested that $\mathrm{Cu}, \mathrm{Zn}$, and $\mathrm{Pb}$ are highly associated with liver tissue while $\mathrm{Cr}$ and $\mathrm{As}$ with muscle and gills. The differences in heavy metal accumulation observed between wild and cultivated Hemibagrus sp. were probably due to the differences in their environmental conditions.
\end{abstract}

Keywords: principal component analysis, pattern recognition, heavy metal, fish, farmed

\section{Abstrak}

Kepekatan $\mathrm{Cr}, \mathrm{Cd}, \mathrm{Cu}, \mathrm{Zn}, \mathrm{Pb}$, dan As dalam pelbagai tisu Hemibagrus sp. dari dua habitat yang berlainan adalah ditentukan dengan pencernaan bantuan gelombang mikro-plasma gadingan teraruh-jirim spektrometri. Objektif kajian ini adalah untuk menentukan perbezaan antara ikan dari habitat semulajadi dan kolam ternakan dari segi pengumpulan logam berat dalam tisu, hati, dan insang. Corak pengumpulan logam berkaitan jenis tisu dan elemen kajian serta habitat ikan ditunjukkan oleh analisis komponen utama. Keputusan menunjukkan bahawa perubahan dalam corak pengumpulan logam adalah bergantung kepada jenis tisu. Keputusan kajian mencadangkan bahawa elemen $\mathrm{Cu}, \mathrm{Zn}$, dan $\mathrm{Pb}$ adalah berkaitan dengan organ hati manakala elemen $\mathrm{Cr}$ dan As adalah berkaitan dengan tisu dan insang. Perbezaan dalam pengumpulan logam berat di antara Hemibagrus sp. dari habitat liar dan kolam ternakan adalah mungkin disebabkan oleh perbezaan dalam keadaan persekitaran mereka. 


\section{Nor Shahirul Umirah et al: EVALUATION OF HEAVY METAL CONCENTRATIONS IN WILD AND CULTIVATED Hemibagrus sp. USING PRINCIPAL COMPONENT ANALYSIS}

Kata kunci: Analisis komponen utama, corak taburan, logam berat, ikan, kolam ternakan

\section{Introduction}

The rapid development of agriculture and industrialization has resulted in increasing of metal pollution in the aquatic ecosystems, which are significantly hazardous for fish and human [1]. Significant quantities of contaminant elements are discharged into river, which can be strongly accumulated and biomagnified along water, sediment and aquatic food chain, thus resulting in sublethal effects or death in fish populations [2-4]. Fish are commonly situated at top of the aquatic food chain and normal metabolism of fish may accumulate large amounts of certain metals from food, water and sediment [5]. Commonly, fish is known to be nutritious with essential proteins, polyunsaturated fatty acids and liposoluble vitamins [6]. Nevertheless, levels of metals in fish are of particular interest due to their high potential to enter and accumulate in food chains [7, 8]. Even low concentrations of these elements have damaging effects to humans and animals because there is no good mechanism for their elimination from the body [9]. On the other hand, fish can be regarded as a good bioindicator because it is easily sampled and found in abundant population, with the potential to accumulate metals and has a long life span with an optimum size for analysis [10]. In this study, heavy metal $(\mathrm{Cr}, \mathrm{Cd}, \mathrm{Cu}, \mathrm{Zn}, \mathrm{Pb})$ of Hemibagrus sp. in certain tissues (gill, liver, muscle) from wild and cultivated habitat are compared. Accumulation pattern relating tissue and elements and the underlying structure related to their origins and tissues were evaluated with principal component analysis (PCA). The aim of PCA is finding the similarities and differences between Hemibagrus sp. of different habitats based on ICP-MS measurement so as to create classification and identification of key discriminants that distinguish between samples.

\section{Materials and Methods}

The slaughtered Hemibagrus sp. was donated in June 2012 by a local fisherman and local fish farmer. The samples originated from the Selangor River and the cultivated pond located at Taman Agroteknologi Pertanian Bistari Jaya, Kuala Selangor, Selangor (Figure 1). The samples were stored in $20^{\circ} \mathrm{C}$ freezer and the length and weight were recorded before dissection. The tissues of muscle, gills, and liver samples were freezing dried (CHRiST, Germany) and the homogenized with a mortar and pestle. Dried samples were kept in amber jars in a desiccator before microwave digestion.

\section{Laboratory procedure}

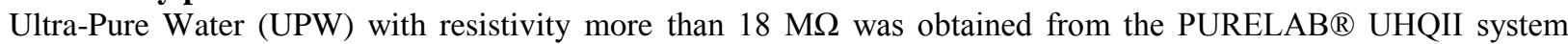
(ELGA®, UK). $65 \%$ nitric acid and $30 \%$ hydrochloric acid solution were of Suprapur ® quality (Merck, Germany). The dogfish liver (DOLT-4) (NRCC, Canada) certified reference material (CRM) for trace metals were used to evaluate the analytical performance of the methods. The tissue samples were analysed according to the method described by Low et al. [11] in which microwave-assisted digestion (MAD) were carried out in a CEM Mar Xpress Microwave Accelerated Reaction System (CEM, Corporation, Matthews, NC, USA). Dried samples (0.25g) was weighted directly in each $55 \mathrm{~mL}$ self-regulating pressure control PFA® vessel and digested with a reagent consists of $2.50 \mathrm{~mL}$ of $65 \% \mathrm{HNO}_{3}, 0.50 \mathrm{~mL}$ of $30 \% \mathrm{HCI}$ and $7 \mathrm{~mL} \mathrm{UPW}$. Under microwave power of $800 \mathrm{~W}$, the microwave temperature was ramped to $185^{\circ} \mathrm{C}$ in $10.5 \mathrm{~min}$ and held for $14.5 \mathrm{~min}$. After digestion, the sample was cooled before being transferred to a $50 \mathrm{~mL}$ polypropylene volumetric flask and the volume was made up to the mark with UPW. Diluted sample solutions were stored in polyethylene vials below $8^{\circ} \mathrm{C}$ and analysed by ICP-MS [12].

\section{Statistical analysis}

Principal component analysis (PCA) was conducted to transform the original data matrix (composed of 120 samples and 5 variables) into a product of two matrices, one which contains information about metal concentrations (loading matrix) and the other about the samples (score matrix). All statistical calculations were performed using the software package JMP version 9.0. 


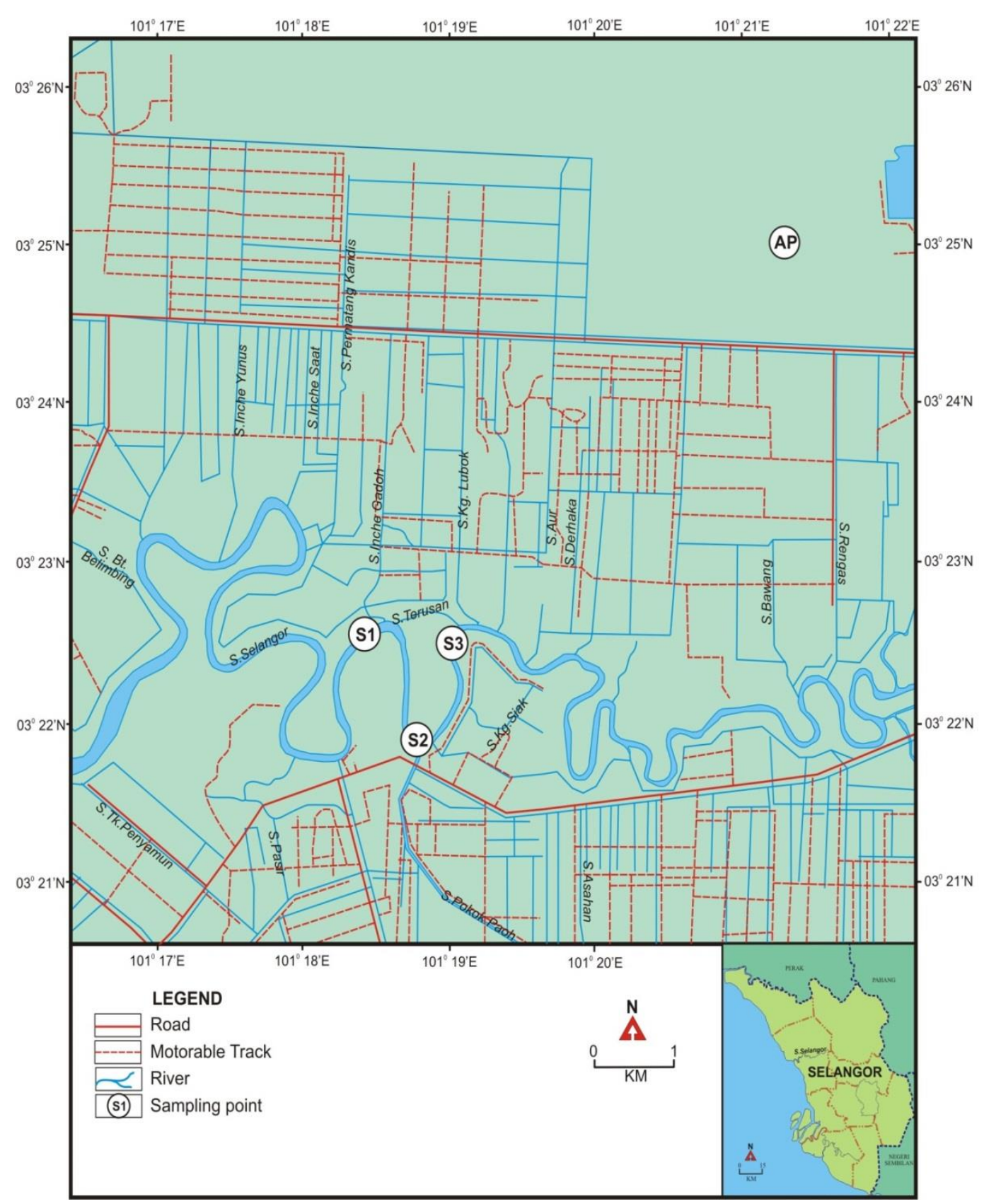

Figure 1. Location of sampling sites, letter S denotes to samples from wild, letter AP denotes cultivated fish.

\section{Results and Discussion}

Certified reference materials of dogfish liver (DOLT-4) were used to check the accuracy of MAD-ICP-MS method. The elemental concentrations determined in the standard reference materials were in a good agreement with the certified values (Table 1). 


\section{Nor Shahirul Umirah et al: EVALUATION OF HEAVY METAL CONCENTRATIONS IN WILD AND CULTIVATED Hemibagrus sp. USING PRINCIPAL COMPONENT ANALYSIS}

Table 1. Analysis of certified reference materials

\begin{tabular}{|c|c|c|c|c|c|c|c|}
\hline & & $\mathrm{Cr}$ & $\mathrm{Cu}$ & Zn & $\mathbf{P b}$ & Cd & As \\
\hline DOLT -4 & Certified values & - & $31 \pm 1$ & $116 \pm 6$ & $0.16 \pm 0.04$ & $24 \pm 0.8$ & $9.7 \pm 0.6$ \\
\hline \multirow[t]{2}{*}{$\left(\mathrm{mg} \mathrm{kg}^{-1}\right)$} & Amount detected & - & $32 \pm 2$ & $118 \pm 7$ & $0.16 \pm 0.04$ & $28 \pm 1.6$ & $9.6 \pm 0.3$ \\
\hline & Recovery / \% & - & $102 \pm 6$ & $102 \pm 5$ & $100 \pm 6$ & $116 \pm 4$ & $99 \pm 3$ \\
\hline
\end{tabular}

$95 \%$ confidence intervals , $n=7$, Note : - not certified

Morphometric data of Hemibagrus sp. from wild and cultivated samples are summarized in Table 2. Condition factor (CF) was calculated by the ratio of weight/length which is commonly used as an index of fish health, while hepatosomatic index (HSI) is defined as the ratio of liver weight to body weight that reflects the energy reserve in fishes[13]. Samples obtained from the cultivated pond were generally smaller than those caught from Selangor River. Although there are differences in size variation, there were no substantial differences noted in the effect of metal concentration in studied tissues [14].

Table 2. Biometric parameters for Hemibagrus sp. from different habitat

\begin{tabular}{|c|c|c|}
\hline \multirow[t]{2}{*}{ Biometric Parameter } & \multicolumn{2}{|c|}{ Habitat } \\
\hline & Aquaculture & Wild \\
\hline Location & $\mathrm{N} 03^{\circ} 25.046 \mathrm{E} 101^{\circ} 21.203$ & $\mathrm{~N} 03^{\circ} 21.883 \mathrm{E} 101^{\circ} 18.728$ \\
\hline Condition factor $(\mathrm{CF})$ & $0.8 \pm 0.2$ & $0.7 \pm 0.0$ \\
\hline Hepatosomatic index (HSI) & $0.7 \pm 0.2$ & $0.7 \pm 0.1$ \\
\hline
\end{tabular}

$95 \%$ confidence intervals, $n=20$

Mean concentrations of heavy metals in the muscle, liver, and gills of wild and cultivated Hemibagrus sp. are presented in Table 3. Chromium, cadmium, copper, zinc, and lead were selected as the analyte elements. There are significant differences $(p<0.001)$ concentrations obtained in different organs. The results have demonstrated that liver tissues generally contained higher concentrations of $\mathrm{Cd}, \mathrm{Cu}, \mathrm{Zn}$, and $\mathrm{Pb}$ for both habitats except for higher $\mathrm{Cr}$ concentrations in the gill tissues. This result is also in a good agreement with Fernandes et al [15], where metal concentrations of $\mathrm{Cu}, \mathrm{Zn}$, and $\mathrm{Pb}$ were higher in liver than other studied tissues. Essential metals such $\mathrm{Cu}$ and $\mathrm{Zn}$ are needed in fish metabolism, while others such as $\mathrm{Pb}$ and $\mathrm{Cr}$ have no functional in biological systems. Our study showed that tissue of wild Hemibagrus sp. contained significantly higher content $(p<0.001)$ of $\mathrm{Pb}$ and As, while tissue of farmed Hemibagrus sp. had significantly higher contents $(p<0.05)$ of $\mathrm{Cu}$. However, all metals may cause harmful effects on fish depending on their concentrations [16]. Overall metal concentrations are generally found to be higher in liver compared to other studied tissues regardless of the sample origins.

The accumulation pattern of metals varies greatly depends on the species as well type of tissues. Previous report by Begum et al. [17], showed that the liver appeared to be the main storage of heavy metal, while the muscle tissue with the lowest level. Yet, Mormede and Davies [18], suggested that the liver is the target organ, which functions to detoxify and accumulate [19], while muscles are at most concern to humans because it is the main tissues of human diet [20]. Based on permissible level limits for the muscle meat of fish, all metal studied were below the permissible level recommended by Malaysian Food Regulation and USEPA risk based concentrations. For a better understanding, PCA was conducted to evaluate the distribution of metals in the studied tissues. PCA is usually discussed in terms of loadings and scores since they complement each other. The scree test proposed by Cattell [21] suggest that with only the first two PCs accounted for $74 \%$ of the total variability of associated metal concentrations in tissues studies and 3 distinct clusters can be revealed (Figure 2). The model demonstrated that Cluster I is made up of liver tissues, Cluster II composed of scores of gill tissues, while the scores of muscle tissues are grouped in 
Cluster III. The variation of these clusters, are totally associated with the type of tissues regardless their habitats. The variation of metal accumulation trends depends on the studied tissues. Combination of the results from Figure 2 and Table 3 suggest that the total metals accumulation is liver $>$ gill $>$ muscle.

Table 3. The concentration of heavy metals in freeze dried Hemibagrus sp.

\begin{tabular}{llcccccc}
\hline & $\begin{array}{l}\text { Tissue } \\
\left(\mathbf{m g ~ k g}^{-1}\right)\end{array}$ & $\mathbf{C r}$ & $\mathbf{C u}$ & $\mathbf{Z n}$ & Pb & Cd & As \\
\hline Aquaculture & Muscle & $0.3 \pm 0.0$ & $1.2 \pm 0.2$ & $33.0 \pm 3.8$ & $0.2 \pm 0.1$ & $<\mathrm{LoD}$ & $0.3 \pm 0.0$ \\
& Liver & $0.3 \pm 0.1$ & $(1.4 \pm 0.2) \times 10^{2}$ & $(1.8 \pm 0.2) \times 10^{2}$ & $1.2 \pm 0.3$ & $<\mathrm{LoD}$ & $0.1 \pm 0.0$ \\
& Gill & $0.4 \pm 0.1$ & $2.9 \pm 0.4$ & $56.1 \pm 4.1$ & $0.2 \pm 0.0$ & $<\mathrm{LoD}$ & $0.6 \pm 0.1$ \\
\multirow{4}{*}{ Natural } & Muscle & $0.3 \pm 0.0$ & $0.8 \pm 0.1$ & $22.8 \pm 1.0$ & $<\mathrm{LoD}$ & $<\mathrm{LoD}$ & $2.3 \pm 0.5$ \\
& Liver & $0.3 \pm 0.0$ & $79.3 \pm 6.8$ & $(1.5 \pm 0.1) \times 10^{2}$ & $5.0 \pm 0.6$ & $<\mathrm{LoD}$ & $0.4 \pm 0.1$ \\
& Gill & $0.4 \pm 0.0$ & $1.6 \pm 0.1$ & $49.8 \pm 3.0$ & $0.9 \pm 0.1$ & $<\mathrm{LoD}$ & $0.9 \pm 0.1$ \\
\hline
\end{tabular}

All reported values are referred to dry base, $95 \%$ confidence intervals, $n=20$, LoD - Limit of Detection $(\mathrm{Pb}<$ $0.03 \mathrm{mg} \mathrm{kg}^{-1}$ )

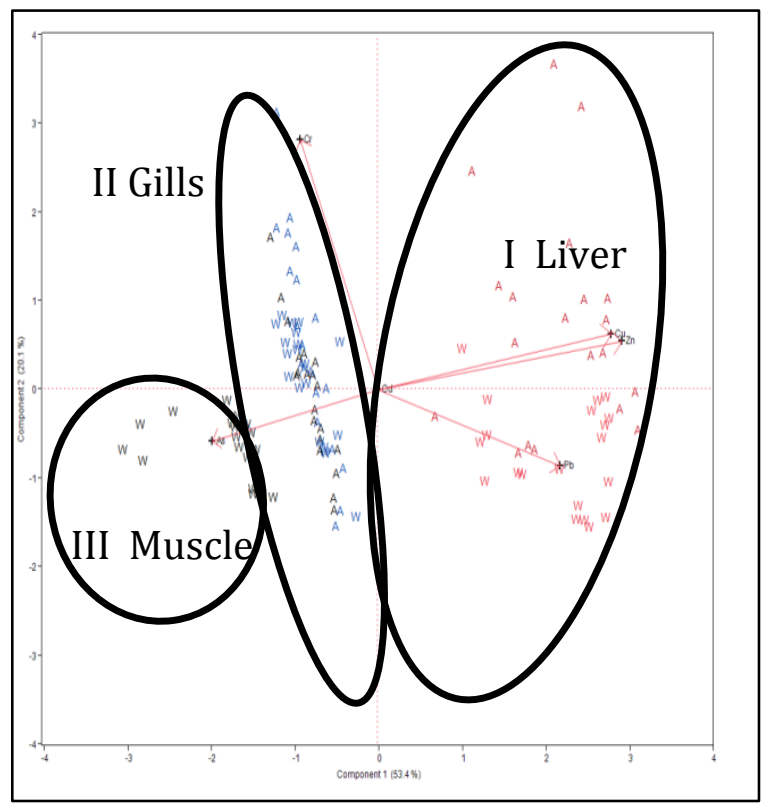

Figure 2. PCA bi-plot for all samples $(n=120)$. The letter A denotes aquacultured fish, letter W denotes to wild fish.

Based on Figure 2, it is noticed that the scores of liver sample (Cluster I) in PC1 axis was spread in the region with positive loadings of $\mathrm{Pb}, \mathrm{Cu}$ and $\mathrm{Zn}$. High variation of these metals makes liver samples stand out more from others on the right-hand side of the scores plot. These observations are consistent with the findings reported by [22], that higher metal accumulation in liver tissues are due to the greater binding tendency of the metals with oxygen carboxylate, amino groups, nitrogen, and/or sulphur of the mercapto group in the metallothionein protein.

PCA bi-plot for liver samples demonstrates two clusters (Figure 3) were obtained. The liver samples from cultivated Hemibagrus sp. have positive scores on PC1 than wild Hemibagrus sp. which explained $52 \%$ of the total variance 
and have positive loadings of $\mathrm{Cr}, \mathrm{Cu}$, and $\mathrm{Zn}$. The gills (Cluster II) and muscle samples (Cluster III) are discriminated from liver samples with negative score on PC1. Nevertheless, Cluster II and Cluster III overlap with high score of $\mathrm{Cr}$ and As. In fact, Cluster III mainly consists of two sub-clusters which can be distinguished by the magnitude of score on PC1 (53\% of total variance). Similar trend was observed in gills samples, where the bi-plot also indicates 2 distinct cluster (Figure 4) (which explained $73 \%$ of the total variances. These results also demonstrated that cultivated Hemibagrus sp. from Selangor River accumulated high metal concentrations than wild Hemibagrus sp.

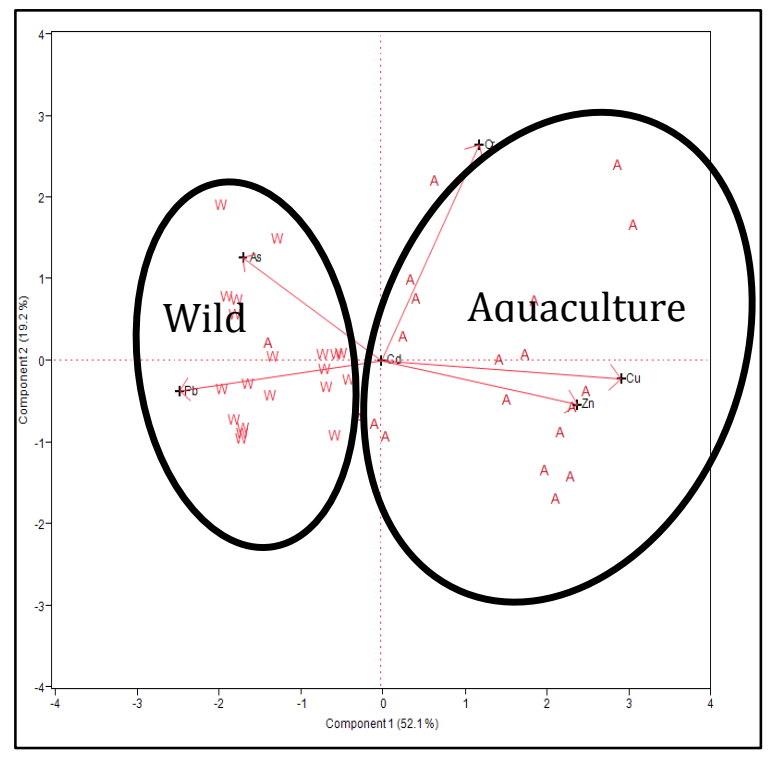

Figure 3. PCA bi-plot for liver samples $(n=40)$.The letter A denotes aquacultured fish, letter W denotes to wild fish.

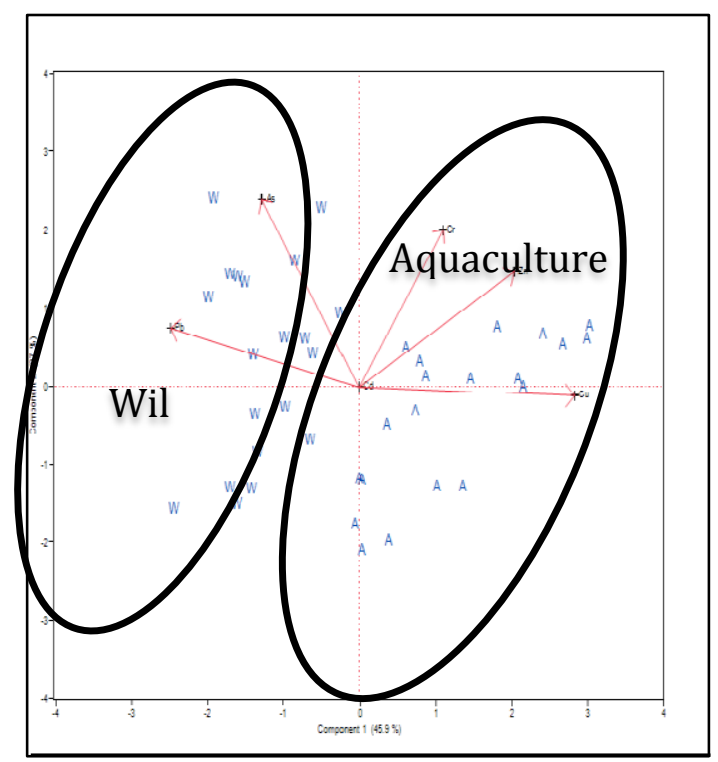

Figure 4. PCA bi-plot for gills samples $(n=40)$. The letter A denotes aquacultured fish, letter $\mathrm{W}$ denotes to wild fish. 
Refer to PCA bi-plot for muscle sample (Figure 5), it was demonstrated that two discrete cluster are separated by PC1 (75\% of total variance), which high positive loadings of $\mathrm{Cu}, \mathrm{Zn}$, and $\mathrm{Pb}$ for cultivated fish while negative loading of $\mathrm{Cr}$ and As for wild fish. According to the Malaysian Food Act 1983 and Food Regulations 1985 [23], accumulation of heavy metal in muscle samples are below the permissible level.

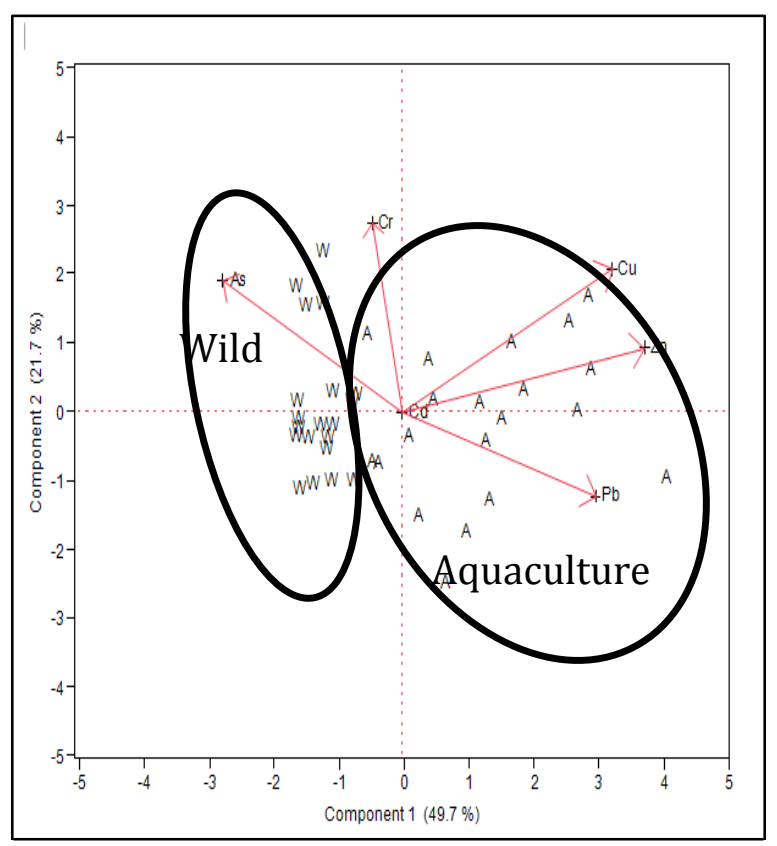

Figure 5. PCA bi-plot for muscle samples $(n=40)$. The letter A denotes aquacultured fish, letter $\mathrm{W}$ denotes to wild fish.

\section{Conclusion}

The results of the study show that PCA can identify patterns in our data, where PCA provides a way to visualize the clustering pattern among different organs of Hemibagrus sp from two different habitats, and easily identifies which metals contribute most to these variation. It also demonstrates the similar clustering tendencies related to the origin of the samples. The results revealed $\mathrm{Cu}, \mathrm{Zn}$, and $\mathrm{Pb}$ highly associated with liver tissues while $\mathrm{Cr}$ and $\mathrm{As}$ with muscle and gills. This suggests that the differences in accumulation of heavy metals between two habitats were probably due to the differences in their environmental conditions.

\section{Acknowledgement}

The authors gratefully acknowledge the financial assistance for this work from the Malaysian Ministry of Science, Technology, and Innovation (ER010-2011A) and Freshwater Fisheries Research Division for technical support during sampling.

\section{References}

1. Uluturhan, E. and Kucuksezgin, F. (2007).Heavy metal contaminants in Red Pandora (Pagellus erythrinus) tissues from the Eastern Aegean Sea, Turkey. Water Research, 41(6): 1185 - 1192.

2. McGeer, J. C., Szebedinszky, C., McDonald, D.G., and Wood, C.M. (2000).Effects of chronic sublethal exposure to waterborne $\mathrm{Cu}, \mathrm{Cd}$ or $\mathrm{Zn}$ in rainbow trout. 1: Iono-regulatory disturbance and metabolic costs. Aquatic Toxicology, 50(3): 231 - 243. 
3. Almeida, J. A., Diniz, Y. S., Marques, S. F. G., Faine, L. A., Ribas, B. O., Burneiko, R. C. and Novelli, E. L. B. (2002).The use of the oxidative stress responses as biomarkers in Nile tilapia (Oreochromis niloticus) exposed to in vivo cadmium contamination. Environment International, 27(8): 673 - 679.

4. Xu, Y. J., Liu, X. Z. and Ma, A. J. (2004).Current research on toxicity effect and molecular mechanism of heavy metals on fish. Marine Science, 28(10): 67 - 70.

5. Yilmaz, F., Özdemir, N., Demirak, A. and Tuna, A. L. (2007).Heavy metal levels in two fish species Leuciscus cephalus and Lepomis gibbosus. Food Chemistry, 100(2): 830 - 835.

6. Gratwicke, B. and Speight, M. R. (2005).The relationship between fish species richness, abundance and habitat complexity in a range of shallow tropical marine habitats. Journal of Fish Biology, 66(3): 650 - 667.

7. Jarić, I., Višnjić-Jeftić, Z., Cvijanović, G., Gačić, Z., Jovanović, L., Skorić, S., and Lenhardt, M., (2011).Determination of differential heavy metal and trace element accumulation in liver, gills, intestine and muscle of sterlet (Acipenser ruthenus) from the Danube River in Serbia by ICP-OES. Microchemical Journal, 98(1): 77 - 81.

8. Burger, J. and Gochfeld, M. (2005).Heavy metals in commercial fish in New Jersey. Environmental Research, 99(3): $403-412$.

9. Chen, Y., Wang, C., and Wang, Z. (2005).Residues and source identification of persistent organic pollutants in farmland soils irrigated by effluents from biological treatment plants. Environment International, 31(6): 778 783.

10. Batvari, B. P. D., Kamala-Kannan, S., Shanthi, K., Krishnamoorthy, R., Lee, K. J. and Jayaprakash, M., (2008).Heavy metals in two fish species (Carangoidel malabaricus and Belone stronglurus) from Pulicat Lake, North of Chennai, Southeast Coast of India. Environmental Monitoring and Assessment, 145(1-3): 167 - 175.

11. Low, K. H., Zain, S. M., and Abas, M. R. (2012).Evaluation of microwave-assisted digestion condition for the determination of metals in fish samples by inductively coupled plasma mass spectrometry using experimental designs. International Journal of Environmental Analytical Chemistry, 92(10): 1161 - 1175.

12. Low, K.H., Zain, S.M., and Abas, M.R., 2011.Evaluation of metal concentrations in red tilapia (Oreochromis spp) from three sampling sites in Jelebu, Malaysia using principal component analysis. Food Analytical Methods, 4(3): 276 - 285.

13. Dethloff, G. M. S., C. J. (2000).Condition factor and organo-somatic indices. U.S. Geological Survey,Information \& Technology Report, USGS/BRD-2000-2005.

14. Anno, G. H., Young, R. W., Bloom, R. M. and Mercier, J. R (2003).Pose response relationship for acute ionizing radiation lethality. Health Physics, 84: 565 - 575.

15. Fernandes, C., Fontaínhas-Fernandes, A., Cabral, D. and Salgado, M. A. (2008).Heavy metals in water, sediment and tissues of Liza saliens from Esmoriz-Paramos lagoon, Portugal. Environmental Monitoring and Assessment, 136(1-3): 267 - 275.

16. Roméo, M., Siau, Y., Sidoumou, Z., and Gnassia-Barelli, M. (1999).Heavy metal distribution in different fish species from the Mauritania coast. Science of the Total Environment, 232(3): 169 - 175.

17. Begum, A., Mustafa, A. I., Amin, M. N., Chowdhury, T. R., Quraishi, S. B., and Banu, N. (2013).Levels of heavy metals in tissues of shingi fish (Heteropneustes fossilis) from Buriganga River, Bangladesh. Environmental Monitoring and Assessment, 185(7): 5461 - 5469.

18. Mormede, S. and Davies, I. M. (2001). Heavy metal concentrations in commercial deep-sea fish from the rockall trough. Continental Shelf Research, 21(8-10): 899 - 916.

19. Uysal, K., Köse, E., Bülbül, M., Dönmez, M., Erdoğan, Y., Koyun, M., Ömeroğlu, Ç., and Özmal, F., (2009).The comparison of heavy metal accumulation ratios of some fish species in Enne Dame Lake (Kütahya/Turkey). Environmental Monitoring and Assessment, 157(1-4): 355 - 362.

20. Shah, A. Q., Kazi, T. G., Arain, M. B., Jamali, M. K., Afridi, H. I., Jalbani, N., Baig, J. A. and Kandhro, G. A. (2009).Accumulation of arsenic in different fresh water fish species - potential contribution to high arsenic intakes. Food Chemistry, 112(2): 520 - 524.

21. Cattell, R. B. (1966).The scree test for the number of factors. Multivariate Behavioral Research, 1(2): 245 276.

22. Al-Yousuf, M. H., El-Shahawi, M. S. and Al-Ghais, S. M. (2000).Trace metals in liver, skin and muscle of Lethrinus lentjan fish species in relation to body length and sex. Science of the Total Environment. 256(2-3): 87 $-94$.

23. Ministry of Health Malaysia (1995).Malaysian Food Act 1983 and Food Regulation 1985. Kuala Lumpur. 